\title{
Impact of Cornell Notes vs. REAP on EFL Secondary School Students' Critical Reading Skills
}

\author{
Samah Zakareya Ahmad ${ }^{1}$ \\ ${ }^{1}$ Faculty of Education, Suez University, Suez, Egypt \\ Correspondence: Samah Zakareya Ahmad, Faculty of Education, Suez University, Suez, Egypt.
}

Received: June 1, 2019

Accepted: July 13, 2019

Online Published: September 29, 2019

doi:10.5539/ies.v12n10p60

URL: https://doi.org/10.5539/ies.v12n10p60

\begin{abstract}
This study compared the effect of two notetaking strategies (Cornell Notes vs. REAP) on EFL secondary school students' critical reading skills. The Alternative Treatment Design with Pretest was used where three intact classes of first-year EFL secondary school students were randomly assigned as a control group and two experimental groups. All participants were administered to a critical reading skills test both before and after the treatment. For 12 weeks, participants in the control group received their regular instruction while those in the first experimental group used Cornell Notes and those in the second experimental group used REAP. Using one-way analysis of variance did not reveal any significant differences among the means of scores of the three groups on the pretest of critical reading skills $(\mathrm{f}=0.36, \mathrm{p}>0.05)$. However, the one-way analysis of variance indicated that significant differences existed among the means of scores of the three groups on the posttest of critical reading skills $(\mathrm{f}=14.45$, $\mathrm{p}<0.05$ ). Moreover, three subsequent independent-samples t-tests comparing posttest scores indicated that students in each experimental group scored significantly higher than those in the control group ( $t=3.90, p<0.05 ; t=5.03$, $p<0.05$, respectively) and that there is no statistically significant difference between means of scores of students in the two experimental groups $(\mathrm{t}=1.35, \mathrm{p}>0.05)$. Therefore, it was concluded that both Cornell Notes and REAP had a significant effect on EFL secondary school students' critical reading skills.
\end{abstract}

Keywords: Cornell Notes, critical reading skills, EFL secondary students, REAP

\section{Introduction}

\subsection{Background to the Problem}

The 21st century information society has provided student readers with a wealth of resources which supported them in pursuing well-founded answers to various critical issues. Nevertheless, this necessitates that students intermingle information from sources expressing various and even contradictory points of view (Bråten \& Braasch, 2017). In other words, students are required to become critical readers.

To be a critical reader means to read critically while as well as after reading (Blakesley \& Hoogeveen, 2012) in order to synthesize, analyze, and evaluate what is read (Van Blerkom, 2012b). In contrast to literal and mechanic reading whose aim is to obtain knowledge (Ateş, 2013), critical reading is to develop an analytical (Van Blerkom, 2012a) neutral comprehension of the text (Mayfield, 2014). It involves: distinguishing fact, opinion, and belief; questioning the author's intentions, argument, and word choice (Blakesley \& Hoogeveen, 2012); and finding the conclusions based on the evidence the writer put forth (Abu Shihab, 2011). Therefore, it requires readers to comprehend not only the content of the text they are reading but also the context in which it was produced (Comber \& Nixon, 2011). In brief, critical readers read beyond what was written to how and why it was written (Rog, 2012).

Several researchers view critical reading as an important life and learning skill (e.g., Jewett, 2007; Zigo \& Moore, 2004) due to many reasons. First, many employers require graduates entering the workplace to have a number of skills including critical reading skills (Camp \& Camp, 2013). Also, critical reading helps readers evaluate arguments; consider commercials, products and advertisements; and judge policies offered by the government (Pirozzi, Starks-Martin, \& Dziewisz, 2014). Moreover, learners might be confused from the huge quantity of information existing on the Internet (Cohen \& Cowen, 2010). Therefore, they need to be taught how to find the required information, how to connect information from different sources, and how to efficiently make use of this information to work out problems (Leu \& Kinzer, 2000).

The ability to critically read complex material is a key predictor of college success as college students need to 
analyze, synthesize, and evaluate what they read. However, critical reading is not adequately developed through schooling (Bråten \& Braasch, 2017). Consequently, most EFL students entering higher education are not usually equipped with the critical reading skills required to cope with college level reading (Lewin, 2005; Magyar, 2012; Şen \& Neufeld, 2006). A survey of recent studies tackling the problem of critical reading skills for Egyptian EFL students showed that many of them suffer from weaknesses in critical reading (Abu Zeid, 2017; Amer, 2017; Badawy, 2018; Bedeer, 2017; Dakhail, 2016; El-Sayed, 2019; Hanafy, 2018; Ismail, 2015; Zaki, 2014). Moreover, the Scholastic Assessment Test ${ }^{\circledR}$ (SAT), critical reading section was administered to 34 EFL students at Shadia Salama Secondary School for Girls. This pilot study revealed that those students scored very low on critical reading skills.

\subsection{Problem Statement}

Based on the survey of recent research as well as the SAT result, the problem of the present study was that there were some weaknesses in Egyptian EFL secondary school students' critical reading skills. For the sake of finding a solution to this problem, the researcher compared the impact of two notetaking strategies (Cornell Notes \& REAP) on EFL secondary school students' critical reading skills.

\subsection{Review of Related Literature}

\subsubsection{Notetaking}

Notetaking is a method of writing down the essential information in a lecture, a meeting, or a reading text rapidly, briefly, and clearly (McPherson, 2018). For a long time, taking notes has been widely used as an important learning method (Chen, Gong, \& Huang, 2015; Nielsen \& Webb, 2011). The ability to take notes is one of the most effective ways to increase students' achievement (Marzano, Pickering, \& Pollock, 2001) as it is one of the research based strategies for: helping learners retain a greater amount of information (Macdonald, 2014), supporting their learning independence (Brunner, 2013), saving their study time (McPherson, 2018), and helping them remain mentally engaged while learning new and challenging material (Brunner, 2013). Therefore, notetaking should be taught as part of the curriculum (Amini Asl \& Kheirzadeh, 2016).

However, students can seldom take notes in a systematic way that supports deeper learning of content due to inability to recognize and encode the most essential points (Brunner, 2013) while connecting the new data to previous information for understanding (Quintus, Borr, Duffield, Napoleon, \& Welch, 2012). It might also be because most students either did not get instruction in how to take notes or received that instruction at a relatively late point in their education (Boyle, 2007). Therefore, students need explicit instruction in notetaking (Dean, Hubbell, Pitler, \& Stone, 2012) in order to be able to improve the quality of their notes (Gray \& Madson, 2007). There are different strategies for notetaking (Macdonald, 2014) including Cornell Notes and REAP (Allen, 2008).

\subsubsection{Cornell Notes}

Cornell Notes is a process for taking notes during reading developed by Cornell University Professor of Education, Walter Pauk (Miller \& Veatch, 2011; Syafi'I, 2019) as a systematic method to master ideas and facts presented in a lecture or a text (Smith, 2017). In this process, students are required to read a text, record notes including the main ideas, reread those notes to form questions, and finally use the notes and questions to write a summary (Gunning, 2012; Honigsfield \& Dove, 2013). The Cornell method involves dividing a page into three different spatial sections: one for main ideas, another for supporting details, and a third for a summary (Crawford, 2015). They then use this form to review, reflect on, and study their notes (Parrish \& Johnson, 2010).

The page is divided vertically into two columns (Brooks, 2016; Fujinami, 2017); the right column is two thirds of the page and the left column is one third of the page (Polleck, 2017; Tsai-Fu \& Wu, 2010) while six or seven lines are left at the bottom of the page (English, 2014) (See Figure 1). The primary notetaking area on the right is where readers record their notes about the main ideas of the text while reading (Beach, Anson, Breuch, \& Reynolds, 2014; Robinson, 2018). On the left column, readers put keywords, thoughts, questions, and observations about the notes on the right column after reviewing them (Werner-Burke \& Vanderpool, 2013). The area at the bottom is preserved for a summary of what readers have learned (Donohoo, 2010). This summary allows them to use their own words to put all the thoughts together after they have learned, recalled, and processed the information from the lecture notes (English, 2014). 


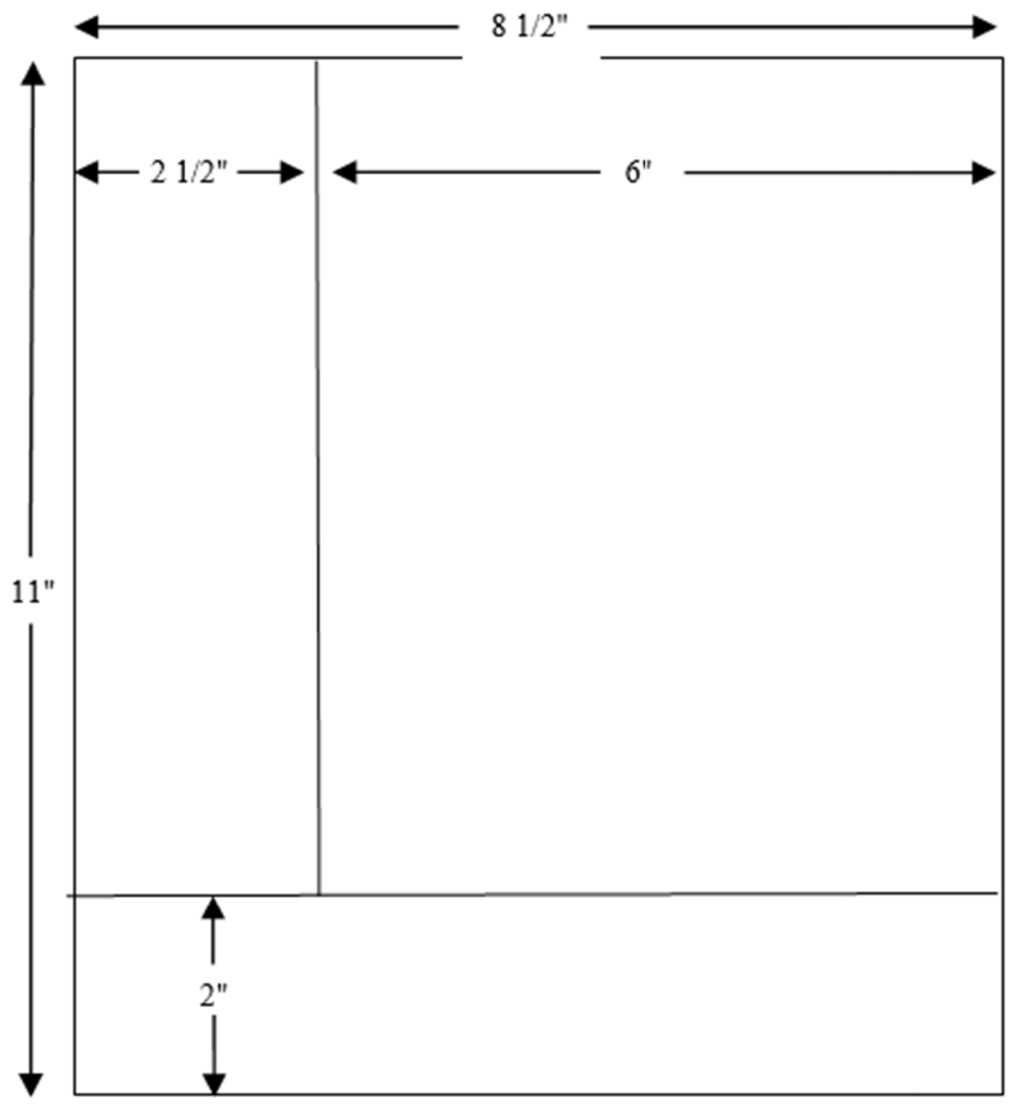

Figure 1. The Cornell Notes sheet, adapted from Pauk (2011, p. 327)

The Cornell Notes strategy takes readers through a structured process of writing down information (Broe, 2013) that can be more effortful than passively copying a lecture (Morehead, Dunlosky, Rawson, Blasiman, \& Hollis, 2019). Three main steps can be identified in that process: pre-reading, during-reading, and post-reading. Before reading the text, students start by drawing a line vertically on the left side of a piece of paper dividing their paper into two columns (Brunner, 2012). Then, two inches from the bottom, students draw a horizontal line across the paper (Broe, 2013). Students then write course name, date, and topic at the top of the page (Pauk, 2011). During reading, students write notes about facts and details in the text on the right side of the page (Johnson, 2013) recording the most important information as concisely as possible (Mcnight, 2010). After reading, students go through their notes; underline main points, key vocabulary terms, dates, and people; and make any scribbles more legible (Forget, 2004). On the left column, they write key ideas and questions that will work as cues for the information on the right (Brunner, 2012). Next, students condense their notes into a four-to-five sentence summary on the bottom of the page (Cho, 2011). Finally, at the back side of the paper, students write reflections on how the information is connected to their personal experiences (Mcnight, 2010) as well as on what they found easy or difficult (Cho, 2011).

Cornell Notes is seen as an excellent notetaking strategy (Berry, 2014) as well as an enhanced thinking process (Johnson, 2013) that can be easily implemented (Brunner, 2012) for whole-group and small-group collaboration as well as for independent learning (Honigsfield \& Dove, 2013) in all content areas (Forget, 2004). Moreover, it is a simple (Akintunde, 2013) time-saving (Davoudi, Moattarian, \& Zareian 2015) learner-directed (Jacobs, 2008) tool for organizing and condensing notes (Rashid \& Rigas, 2006) that promotes active learning (Brunner, 2012), encourages critical reflection (Burns \& Sinfield, 2004), facilitates student engagement (Zhang, Dang, \& Amer, 2016), increases student confidence (Evans \& Shively, 2019), and allows for the retention of great quantities of information (Donohoo, 2010). Additionally, it is great for those who are new to taking notes (Hayati \& Jalilifar, 2009) as it helps them extract the most important information from a text (Thomson \& Kalmer, 2016), organize it in a useful format (Forget, 2004), and understand why this information is important and why they have noted it (Burns \& Sinfield, 2012). Moreover, Cornell Notes helps students remember what they read (Johnson, 2013), 
become more efficient in the learning process, and acquire metacognitive skills (Forget, 2004). It also has a significant effect on students' comprehension (Fisher, Frey, \& Lapp, 2009), achievement (Broe, 2013), scores (Donohoo, 2010), and success (Kubacak, 2017). Finally, it enables teachers to monitor the students' level of comprehension through reading their reflections (Cho, 2011).

Some educators offered some guidelines for using the Cornell Notes strategy. For example, Bernadowski, Del Greco, and Kolencik (2013) suggest that teachers should model this strategy with students before asking them to use it on their own. Moreover, Pauk (2011) advises students to skip a line between ideas and topics, not to use complete sentences, and to use abbreviations, whenever possible. Also, Broe (2013) advises them to decrease important ideas from the notes and record them in the left-hand column as soon as possible after reading. He also recommends that they cover the right part of the paper and use the questions or key terms on the left to try to self quiz or recite in order to retain the knowledge they wrote down. Finally, Johnson (2013) believes that the real learning power comes when students think and reflect about what was read.

\subsubsection{REAP}

REAP is a notetaking strategy introduced by Marilyn Eanet and Anthony Manzo at the University of Missouri-Kansas City (Powell, Cleveland, Thompson, \& Forde, 2012) for helping readers to think more precisely about what they read (Santi, 2015) in order to improve their comprehension of content within that text (Brunner, 2012). The term REAP is an acronym for Read, Encode, Annotate, and Ponder (Tiruneh, 2014). It suggests that students read the material, encode the gist of what they read into their own words, respond to the material by writing different types of annotations from several perspectives, and, finally, ponder what they have read and written through thinking about the material and sharing reactions with others (Roe \& Smith, 2012; R. Vacca, J. Vacca, \& Mraz, 2016). The REAP strategy may be used with students working independently or with groups (Ruddell, 2007) and it is based on the premise that readers have the highest levels of attention and comprehension when they are to communicate information they have obtained from a text they have read (Tasdemir, 2010).

Educators suggest that there are certain steps to follow when using REAP. As its name suggests, there are four key steps: reading, encoding, annotating, and pondering. In the first step, students read a selection on their own (Syrja, 2011) in order to identify the main points (Brunner, 2012). In the encoding step, students restate the gist of what they read in their own words (Northey, 2005). In the next step, students annotate the text by making notes for personal use (Powell et al., 2012) about the main ideas and the author's message (Allen, 2008). Different types of REAP annotations are described in Figure 2, below. Finally, students ponder what they have read through thinking about it and discussing it with others (Powell et al., 2012) in order to check their comprehension (Syrja, 2011), develop questions about the topic, and connect this reading to other reading they have done (Allen, 2008).

\section{Summary Annotation: simple statement of the main ideas}

2. Telegram Annotation: telegram-like message of the author's basic theme

3. Poking Annotation: restatement of a lively part of the text that makes the reader want to respond

4. Question Annotation: turning the main idea into a question

5. Personal View Annotation: comparing the views and feelings of the reader to what the author said

6. Critical Annotation: supporting, rejecting, or questioning the main idea

7. Contrary Annotation: stating a contrary position

8. Intention Annotation: explaining the author's intention and purpose

9. Motivation Annotation: speculation on what may have caused the author to write the text

10. Discovery Annotation: questioning practical issues in the text that require further explanation

11. Creative Annotation: writing better views, solutions, or endings

Figure 2. REAP Annotation Types, adapted from A. Manzo and U. Manzo (1995, p. 358)

Many researchers addressed the advantages of the REAP strategy. It was described as a powerful and flexible strategy (Beach \& O'brien, 2015) that: facilitates the recall and summarization of information (Hathaway, 2014), allows for the consideration of more than one point of view, requires little advance preparation from the teacher 
(Brunner, 2012), and enhances students' abilities to work in groups (Marantika \& Fitrawati, 2013). Moreover, the REAP helps students read texts for different purposes (Rojas, 2007) without having to understand the meaning of each word (Clark, 2014). It also helps them interact with the text (Tiruneh, 2014) and connect their prior knowledge to text information (Rojas, 2007) which enables them to answer questions on that text (Lapp \& Fisher, 2009) as well as generate questions to further understanding (Rojas, 2007). Moreover, this strategy helps students build a bridge between the text and their own words (Hathaway, 2014) as well as helps them initiate self-correction strategies (Rojas, 2007). Additionally, REAP incorporates higher order thinking and analysis (Powell et al., 2012) and expands students' critical thinking (Brunner, 2012) as it helps them synthesize the author's thoughts in their own words (Tasdemir, 2010). It also helps them draw conclusions, make inferences, evaluate ideas, identify hidden agendas, and make connections between the text being read and texts read in the past (Rojas, 2007).

Some educators offered some guidelines for using the REAP strategy. For example, Brunner (2012) suggests giving each student note cards and asking them to use the cards to restate what they want to remember from the text. Rojas (2007) suggests that students fill in the sections of a chart (Figure 3) reflecting their responses to each of the four REAP stages. More guidelines are introduced for carrying out each step of the REAP strategy. As for the reading step, it is suggested that teachers begin by having a discussion starter to make students think about the topic and then ask them to read and fill in the "R" section of the chart with the title and the author (Allen, 2008). Teachers are also recommended to allow opportunities for students to check their understanding particularly when they are reading complex texts (Syrja, 2011). During the encoding step, it is important for the ideas generated to stem from students' own thoughts (Powell et al., 2012) and students should be able to paraphrase without having to reread the materials (Clark, 2014). Moreover, Esteves and Whitten (2014) suggest that during the encoding step each student should create a personal vocabulary list where he/she adds any new or unfamiliar word along with a meaningful definition. In the annotation step, teachers should explain different types of annotations and display an example of each type (Brunner, 2012). Teachers are also advised to prompt students with some questions (e.g., What is the author's intention? What is the problem presented in the passage? What are some possible solutions?) (Clark, 2014). In the pondering step, the class should be divided into small groups for the purpose of sharing information from the note cards (Brunner, 2012).

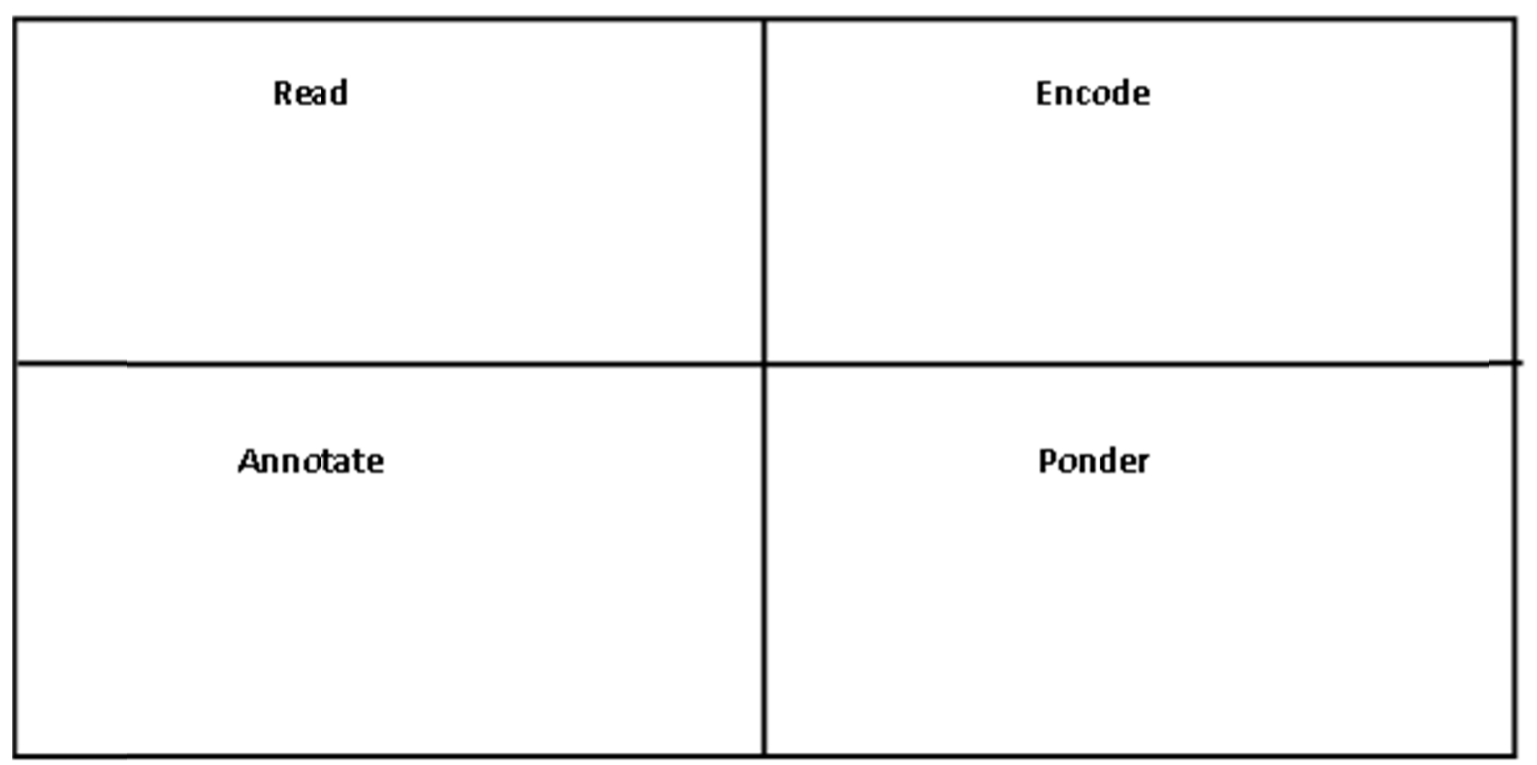

Figure 3. REAP Chart, adapted from Rojas (2007)

\subsubsection{Cornell Notes vs. REAP on Critical Reading}

While many studies found a positive effect for Cornell Notes (e.g., Domenico, Elish-Piper, Manderino, \& L'Allier, 2018; Evans \& Shively, 2019; Nuraeni, 2019) or REAP (e.g., Amalia, Inderawati, \& Erlina, 2018; Cahyaningtyas \& Mustadi, 2018; Fadhli, 2015; Fadhli \& Suhaimi, 2017; Juniardi, Suharjito, Andayani, 2019; Mehmet, 2010; Mutia, Syafar, \& Dewi, 2016; Santi, 2015; Zasrianita, 2016) on reading comprehension, less studies found a positive effect for Cornell notes (e.g., Jacob, 2008) or REAP (e.g., Fitriastuti, 2013; Pohtong, 2012) on critical reading. However, as far as the researcher knows, no study compared the impacts of Cornell Notes vs. REAP on 
critical reading. Therefore, the researcher decided to compare the impacts of Cornell Notes vs. REAP on EFL secondary school students' critical reading skills.

\subsection{Hypotheses of the Study}

1) No statistically significant difference $(\alpha \leq 0.05)$ would exist in EFL secondary school students' means of scores in the critical reading skills posttest among the three groups (the control group and the two experimental groups).

2) No statistically significant difference $(\alpha \leq 0.05)$ would exist in EFL secondary school students' means of scores in the critical reading skills posttest between the first experimental group exposed to Cornell Notes and the control group.

3) No statistically significant difference $(\alpha \leq 0.05)$ would exist in EFL secondary school students' means of scores in the critical reading skills posttest between the second experimental group exposed to REAP and the control group.

4) No statistically significant difference $(\alpha \leq 0.05)$ would exist in EFL secondary school students' means of scores in the critical reading skills posttest between the first experimental group exposed to Cornell Notes and the second experimental group exposed to REAP.

\section{Method}

\subsection{Research Design}

The design used in this study was the Alternative Treatment Design with Pretest (Salkind, 2010), an experimental design that compares the effectiveness of two alternative treatments (Rubin \& Babbie, 2017). Using this design, the researcher randomly assigned three intact classes to three groups: one control group that received regular instruction as well as two experimental groups (one used Cornell Notes and the other used REAP). Each group was tested on critical reading skills before and after the experimental groups received the intervention. Differences among the three groups in both the pretests and the posttests were calculated. Additionally, differences between each two groups were evaluated.

\subsection{Variables}

Two independent variables (Cornell Notes and REAP) as well as one dependent variable (critical reading skills) were included in the study. They are operationally defined as follows:

\subsubsection{Cornell Notes}

Cornell Notes is a strategy for taking notes from the reading material that consists of: dividing a sheet of paper into three parts, previewing the reading material, recording notes about important details on the right column, reducing them into main ideas and key words in the left column, summarizing the main ideas on the bottom of the page, reflecting on them, and reviewing them from time to time.

\subsubsection{REAP}

REAP is a strategy for taking notes from the reading material that consists of: dividing a blank sheet of paper into a window-shaped organizer of four quadrants, previewing the reading material, reading it to write the title and the author in the "R" section, putting the gist of what was read in the "E" section, writing at least three different annotations in the " $\mathrm{A}$ " section, writing about what was learned from the text in the "P" section, and presenting and discussing the notes in class.

\subsubsection{Critical Reading}

Critical reading is EFL secondary school students' ability to: determine the central claim of the text, decide the audience of the text, infer omitted words, anticipate the author's attitude towards particular issues, identify the use of irony and humor in a text, identify exaggeration, identify solutions to problems in the reading text, guess the author's intended meaning, distinguish fact and opinion, examine the evidence the text employs, make judgments about context, and find ambiguity.

\subsection{Participants}

Participants were 123 students at three intact classes of first-year EFL secondary school students at Shadia Salama Secondary School for Girls, Suez Governorate, Egypt. The three classes were randomly assigned as groups of the study. The first class was assigned to the control group ( $\mathrm{n}=42$ students), the second to the first experimental group using Cornell Notes $(n=40)$, and the third for the second experimental group using REAP $(n=41)$. Participants ranged between 15-16 years of age and spent at least 9 years learning English. 


\subsection{Measure}

A test of critical reading skills was prepared by the researcher. Twenty-four multiple-choice questions were included in the test along with five reading passages. Three passages were followed by four questions and two passages were followed by six questions. Each question had four options. Questions covered the 12 skills mentioned above in the operational definition of critical reading, two questions for each skill.

The total score of the test was 24 points. Criterion validity was achieved by administering the test along with the SAT Critical Reading Test, to a group of first-year EFL secondary school students. Pearson's Coefficient of correlation between students' scores on the devised critical reading test and their scores on the SAT was 0.77 (significant at the 0.01 level). For reliability, the test was administered twice, with a two-week interval. Pearson's Coefficient of correlation between students' scores on the two administrations was 0.83 (significant at the 0.01 level).

\subsection{Procedures}

Procedures were carried out during the first term of the 2016/2017 academic year. These procedures were divided into four consecutive stages: 1) pretesting, 2) training, 3) treatment, and 4) posttesting. First, all participants were pretested on critical reading skills and one-way analysis of variance revealed no statistically significant differences among the means of scores of the three groups $(\mathrm{f}=0.36, \mathrm{p}>0.05)$ (See Table 1$)$.

Table 1. One-way analysis of variance for the three groups on the pretest of critical reading skills

\begin{tabular}{lccccc}
\hline Source & Sum of Squares & Df & Mean Square & F & Probability. \\
\hline Between Groups & 11.70 & 2 & 5.85 & & \\
Within Groups & 1957.93 & 120 & 16.32 & 0.36 & 0.70 \\
Total & 1969.63 & 122 & & & \\
\hline
\end{tabular}

After pretesting, students in each experimental group were trained in the strategy assigned to them. That is, the first experimental group received orientation in Cornell Notes while the second experimental group received orientation in REAP. Each group received the training during a two-hour session at the beginning of the semester. The researcher began by introducing students in each group to the assigned strategy in depth explaining its steps and what was expected from them during each step. She also explained its benefits and the points they should consider while using it. The researcher modeled the assigned strategy for the students and taught them how to take notes using it as well as how to draw the graphic organizers that would be used to record their ideas while using each strategy. Later on, the researcher gave students weekly 15-minute training sessions over the course of the treatment.

For 12 weeks, participants in the two experimental groups received their treatment where the first experimental group used the Cornell Notes strategy and the second experimental group used the REAP strategy. During this time, participants in the control group received their usual instruction. The same reading texts were used by the three groups during the treatment. Application of both Cornell Notes and REAP is explained below.

\subsubsection{Applying Cornell Notes}

\subsubsection{Creating Format}

Each student divided a piece of paper into three sections by drawing a line vertically on the left side of the paper dividing it into two columns and then drawing a horizontal line, two inches from the paper's bottom. The left-hand column took about one third of the writing space, leaving the remaining two thirds for the right-hand column. Students wrote course name, date, and topic at the top of each page.

\subsubsection{Previewing}

Students previewed the reading material they were about to read, looked at the title and subheadings, and read the first and last paragraphs. They also generated some questions they thought of as they were previewing and listed them in the left part of the paper.

\subsubsection{Recording}

During reading, students used the notetaking column on the right part of the paper to write notes in their own words. They recorded important facts and details in the text using telegraphic sentences, abbreviations, and symbols instead of complete sentences. However, they recorded definitions as stated. They indicated changes in topic with headings or by skipping a line between ideas and topics. 


\subsubsection{Reducing}

After finishing reading and recording notes, students read through their notes and reduced and synthesized them in the left column, making them as concise as they could. They wrote the main ideas, key words, and important vocabulary. Moreover, they formulated questions based on the notes they previously wrote in the right-hand column.

\subsubsection{Reciting}

Students covered up the notes in the right column and used the clues in the left column to recite the relevant information. They answered the questions, defined terms, and told what they remembered about the key words. If they had difficulty recalling the information or if their answers were incorrect, they reread their notes, covered them, and recited over again.

\subsubsection{Summarizing}

Students summarized the main ideas into a three-to-four-sentence summary on the bottom of the page. They frequently shared their summaries with the class. Through class discussion, they collaborated to edit peers' summaries.

\subsubsection{Reflecting}

On the back side of the Cornell Notes sheet, students reflected on the material by asking themselves about the significance of these facts, how they could be applied, how they were connected to students' experiences, how they fitted in with what they already knew, what students agreed with, what they disagreed with, which ideas were clear, which were confusing, and what new questions they had.

\subsubsection{Reviewing}

Students rehearsed information immediately after they finished the reflecting step. Moreover, they practiced the information several times during the week to help keep the information active and accessible in their memory. At the end of each week, they spent at least ten minutes reviewing all their previous notes.

\subsubsection{Applying REAP}

\subsubsection{Creating Format}

Students created the REAP chart through dividing a blank sheet of paper into a window-shaped organizer of four quadrants: the "R" quadrant to record the title and the author of the text, the "E" quadrant to rephrase the main ideas in students" own words, the "A" quadrant to put a summary of the important points, and the "P" quadrant to record what the writer wanted the readers to learn from the text.

\subsubsection{Previewing}

The researcher divided the class into discussion groups consisting of three to five students. She showed some pictures as well as the title of the text and asked some questions to help students build their background knowledge about the topic. Groups discussed the topic then one member from each group told the whole class what was discussed in her group.

\subsubsection{Reading}

Students read the text on their own to get an overall understanding of what the author was saying. Then, they wrote the title and the author of the text in the "R" section of the chart. The researcher asked individual students to read the text aloud and finally the researcher read the text for the class and stopped at various points to make sure that students understood what was being read to them.

\subsubsection{Encoding}

In the "E" box, students put the gist of what they read using their own words. In the same box, they wrote some of the difficult or new vocabulary in the text. In their small groups, students discussed the main ideas of the text and came up with a list of what they were. After that, the researcher led a whole class discussion about the main ideas of the text and the meaning of the difficult vocabularies with the students.

\subsubsection{Annotating}

Students read the text again and made notes for personal use about the text. From the 11 types of annotations (See Figure 2), students were required to choose at least three annotation types to write in the "A" section. Students returned to their small groups to discuss their annotations and to offer constructive suggestions to one another. 


\subsubsection{Pondering}

Students thought about what they had read and asked themselves about the purpose of the text, what the text meant to them, and how they could relate their personal experiences and previous readings to it. In the "P" column, students wrote about what they learned from the text as well as the questions to be discussed in their groups. In their small groups, students shared their ideas, facts, feelings, and questions, then made one perfect summary about the text given to them.

\subsubsection{Confirmation}

After students had completed their REAP charts, they were invited to present their notes in front of the class. Then, a discussion was conducted on what students have learned about the content and their personal preferences as notetakers. Finally, the researcher gave feedback to the students, summarized the text, and gave the moral value from it.

\section{Results}

Using one-way analysis of variance indicated that significant differences existed among the means of scores of the three groups (one control group and two experimental groups) on the posttest of critical reading skills ( $\mathrm{f}=14.45$, $\mathrm{p}<0.05$ ) (See Table 2).

Table 2. One-way analysis of variance for the three groups on the posttest of critical reading skills

\begin{tabular}{lccccc}
\hline Source & Sum of Squares & df & Mean Square & F & Probability. \\
\hline Between Groups & 464.09 & 2 & 232.04 & & \\
Within Groups & 1927.39 & 120 & 16.06 & 14.45 & .00 \\
Total & 2391.48 & 122 & & & \\
\hline
\end{tabular}

Moreover, three subsequent independent-samples t-tests were employed to compare the differences for each two groups. See Table 3 for the mean difference for each two groups on the posttest of critical reading skills.

Table 3. Mean difference for each two groups on the posttest of critical reading skills

\begin{tabular}{lccccc}
\hline Group & N & M & S. D. & t-value & Probability. \\
\hline Control group & 42 & 10.79 & 4.05 & \multirow{2}{*}{3.90} & 0.00 \\
1st Experimental Group (Cornell Notes) & 40 & 14.15 & 3.75 & & \\
Control group & 42 & 10.79 & 4.05 & \multirow{2}{*}{5.03} & 0.00 \\
2nd Experimental Group (REAP) & 41 & 15.34 & 4.20 & & \\
1st Experimental Group (Cornell Notes) & 40 & 14.15 & 3.75 & \multirow{2}{*}{1.35} & 0.18 \\
2nd Experimental Group (REAP) & 41 & 15.34 & 4.20 & & \\
\hline
\end{tabular}

As shown in Table 3, results from the t-tests indicated that students in the first experimental group and the second experimental group scored significantly higher than those in the control group $(t=3.90, p<0.05 ; t=5.03, p<0.05$, respectively). The table also shows that there is no statistically significant difference between means of scores of students in the two experimental groups $(\mathrm{t}=1.35, \mathrm{p}>0.05)$.

\section{Discussion}

The first hypothesis of the present study was that no statistically significant difference $(\alpha \leq 0.05)$ would exist in EFL secondary school students' means of scores in the critical reading skills posttest among the three groups (the control group and the two experimental groups). One-way analysis of variance comparing the means of scores of the three groups on the posttest of critical reading skills revealed significant differences $(\mathrm{f}=14.45, \mathrm{p}<0.05)$. Based on this result, the researcher rejected the hypothesis.

The second hypothesis of the present study was that no statistically significant difference $(\alpha \leq 0.05)$ would exist in EFL secondary school students' means of scores in the critical reading skills posttest between the first experimental group exposed to Cornell Notes and the control group. An independent-samples t-test showed a significant difference between the means of scores of the two groups $(t=3.90, p<0.05)$. Based on this result, the researcher rejected the hypothesis and concluded that Cornell Notes had a significant effect on the critical reading skills of EFL secondary school students. This result might find support in the finding of Jacob's (2008) study which found that the Cornell Notes method helped students become better able to answer higher-level questions 
and was effective when analysis, synthesis, or evaluation was required from students. An explanation for this result is that during using Cornell Notes, students of the first experimental group analyzed, synthesized, and evaluated what they read (i.e., they practiced critical reading). Students analyzed the text they read and wrote notes in their own words about important facts and details in the right column and then synthesized their notes in the left column in the form of main ideas and questions as well as a summary of the main ideas on the bottom of the page. Moreover, they evaluated what they read through reflecting and asking themselves about the significance of the information in the text, whether they agreed or disagreed with it, and how it could be applied.

The third hypothesis of the present study was that no statistically significant difference $(\alpha \leq 0.05)$ would exist in EFL secondary school students' means of scores in the critical reading skills posttest between the second experimental group exposed to REAP and the control group. An independent-samples t-test indicated a significant difference between the means of scores of the two groups $(t=5.03, p<0.05)$. Based on this result, the researcher rejected the hypothesis and concluded that REAP had a significant effect on the critical reading skills of EFL secondary school students. This result might find support in the findings of two studies which found that students who used REAP improved in critical reading (Fitriastuti, 2013; Pohtong, 2012). An explanation for this result is that during using REAP, students of the second experimental group also practiced critical reading through analyzing, synthesizing, and evaluating what they read. Students analyzed the text through identifying and discussing the main ideas and difficult vocabulary in it. Then, they synthesized them when they wrote the gist of what they read as well as different types of annotations which they discussed in small groups. Moreover, they evaluated what they had read by asking themselves about the purpose of the text, what they learned from it, and how they could connect their experiences to it. This explanation goes along with the opinions of some educators that REAP is a critical reading strategy that helps students connect with the text at a higher level (Tiruneh, 2014) through going beyond the author's ideas (Sejnost \& Thiese, 2010) and thinking more deeply about what they read (Fadhli, 2015) in order to analyze how the author's attitude affects his/her writing (Hathaway, 2014) and to evaluate the message in the text (Bean, Baldwin, \& Readence, 2012). It also helps students construct deeper meaning of the text (Sejnost \& Thiese, 2010) as they build a bridge between the text and their own words to enable them to communicate their understanding of the text (Clark, 2014) as well as draw logical conclusions based on evidence from the text (Esteves \& Whitten, 2014).

The fourth hypothesis of the present study was that no statistically significant difference $(\alpha \leq 0.05)$ would exist in EFL secondary school students' means of scores in the critical reading skills posttest between the first experimental group exposed to Cornell Notes and the second experimental group exposed to REAP. An independent-samples t-test indicated no significant difference between the means of scores of the two groups $(\mathrm{t}=1.35, \mathrm{p}>0.05)$. Therefore, the researcher accepted the hypothesis and concluded that both Cornell Notes and REAP developed EFL secondary school students' critical reading skills. Since students in the three groups were at the same level of critical reading skills at the beginning of the study and performed quite differently at the end, it can be inferred that the difference was due to the use of the two notetaking strategies: Cornell Notes and REAP. This is supported by the assertion of Çetingöz's (2010) and Tsai-Fu and Wu (2010) that explicit, sustained instruction and support with notetaking help students and increase their learning quality.

\section{Conclusion}

In light of the results of the present study, the researcher concluded that both Cornell Notes and REAP strategies improved the critical reading skills of EFL secondary school students.

\section{Recommendations and Suggestions}

The researcher recommended that: 1) secondary school teachers be encouraged to infuse the instruction of notetaking strategies into different subjects of study, 2) developing critical reading skills be devoted more attention, and 3) instructors teach a variety of notetaking strategies so that students can choose the one(s) that suit(s) their learning objectives as well as the nature of the text they read. Moreover, the researcher suggested conducting some research studies to tackle: 1) the effect of different notetaking strategies on EFL students' listening comprehension, 2) the effect of web-supported notetaking (e.g., iREAP) on EFL students' reading comprehension, and 3) teachers' and students' attitudes towards using notetaking strategies.

\section{References}

Abu Shihab, I. (2011). Reading as critical thinking. Asian Social Science, 7(8), 209-218. https://doi.org/10.5539/ass.v7n8p209

Abu Zeid, H. (2017). The effect of using a blended e-learning program based on metacognition on developing first year secondary school students' critical reading \& critical writing skills (Unpublished doctoral 
dissertation). Minia University, Egypt.

Akintunde, O. (2013). Effects of Cornell, verbatim \& outline note-taking strategies on students' retrieval of lecture information in Nigeria. Journal of Education \& Practice, 4(25), 67-74.

Allen, J. (2008). More tools for teaching content literacy. Portland, MA: Stenhouse.

Amalia, F., Inderawati, R., \& Erlina, E. (2018). Reading comprehension achievement on narrative text by using REAP strategy. English Language Education \& $\quad$ Literature, 3(1), 1-7. https://doi.org/10.30599/channing.v3i1.264

Amer, A. (2017). A problem-based learning program to enhance EFL critical reading, creative writing \& problem-solving skills of secondary stage students (Unpublished doctoral dissertation). Zagazig University, Egypt.

Amini Asl, Z., \& Kheirzadeh, S. (2016). The effect of note-taking \& working memory on Iranian EFL learners' listening comprehension performance. International Journal of Research Studies in Psychology, 5(4), 41-51. https://doi.org/10.5861/ijrsp.2016.1583

Ateş, S. (2013). Critical reading \& its teaching as a skill. Turkish Journal of Education, 2(3), 40-49.

Badawy, M. (2018). Evaluating \& developing critical reading skills using an interactive digital storytelling environment for third year preparatory students (Unpublished doctoral dissertation). Kafrelsheikh University, Egypt.

Beach, R., \& O'brien, D. (2015). Using apps for learning across the curriculum: A literacy-based framework \& guide. New York: Routledge. https://doi.org/10.4324/9781315769127

Beach, R., Anson, C., Breuch, L., \& Reynolds, T. (2014). Understanding \& creating digital texts: An activity-based approach. Lanham: Rowman \& Littlefield.

Bean, T., Baldwin, S., \& Readence, J. (2012). Content-area literacy: Reaching \& teaching the $21^{\text {st }}$ century adolescent. Huntington Beach: Shell Education.

Bedeer, F. (2017). The effect of a brain-based learning program on developing primary stage students' English language critical reading skills (Unpublished doctoral dissertation). Ain Shams University, Egypt.

Bernadowski, C., Del Greco, R., \& Kolencik, P. (2013). Using tradebooks \& databases to teach our nation's history: Grades 7-12. Santa Barbara: Libraries Unlimited.

Berry, G. (2014). Literacy for learning: A handbook of content-area strategies for middle \& high school teachers. Lanham: Rowman \& Littlefield.

Blakesley, D., \& Hoogeveen, J. (2012). Writing: A manual for the digital age (2nd ed.). Boston, MA: Wadsworth Cengage Learning.

Boyle, J. (2007). The process of note taking: Implications for students with mild disabilities. The Clearing House, 80(5), 227-232. https://doi.org/10.3200/TCHS.80.5.227-232

Bråten, I., \& Braasch, J. (2017). Key issues in research on students' critical reading \& learning in the $21^{\text {st }}$ century information society. In $\mathrm{C} . \mathrm{Ng}, \& \mathrm{~B}$. Bartlett (Eds.), Improving reading \& reading engagement in the $21^{s t}$ century (pp. 77-98). Gateway East, Singapore: Springer Nature. https://doi.org/10.1007/978-981-10-4331-4_4

Broe, D. (2013). The effects of teaching Cornell Notes on student achievement (Unpublished master's thesis). Minot State University, North Dakota.

Brooks, M. (2016). Notes \& talk: An examination of a long-term English learner reading-to-learn in a high school biology classroom. Language \& Education, 30(3), 235-251. https://doi.org/10.1080/09500782.2015.1102275

Brunner, J. (2012). Now I get it: Differentiate, engage, \& read for deeper meaning. New York: Rowman \& Littlefield.

Brunner, J. (2013). Doing what works: Literacy strategies for the next level. New York: Rowman \& Littlefield.

Burns, T., \& Sinfield, S. (2004). Teaching, learning, \& study skills: A guide for tutors. London: Sage.

Burns, T., \& Sinfield, S. (2012). Essential study skills: The complete guide to success at university (3rd ed.). London: Sage.

Cahyaningtyas, A., \& Mustadi, A. (2018). The effect of REAP strategy on reading comprehension. SHS Web of 
Conferences, 42, 1-6. https://doi.org/10.1051/shsconf/20184200014

Camp, D., \& Camp, W. (2013). Using content reading assignments in a psychology course to teach critical reading skills. Journal of the Scholarship of Teaching \& Learning, 13(1), 86-99.

Çetingöz, D. (2010). University students' learning processes of note-taking strategies. Procedia Social \& Behavioral Sciences, 2, 4098-4108. https://doi.org/10.1016/j.sbspro.2010.03.647

Chen, G., Gong, C., \& Huang, R. (2015). Note-taking in pupil's textbook: Features \& influence factors. In M. Chang, \& Y. Li (Eds.), Smart learning environments (pp. 95-110). Berlin: Springer. https://doi.org/10.1007/978-3-662-44447-4_6

Cho, J. (2011). Improving science learning through using interactive science notebook (ISN). In P. Gouzouasis (Ed.), Pedagogy in a new tonality (pp. 149-166). Rotterdam, the Netherlands: Sense Publishers. https://doi.org/10.1007/978-94-6091-669-4_10

Clark, S. (2014). Writing strategies for science (2nd ed.). Huntington Beach: Shell Education Corwin.

Cohen, V., \& Cowen, J. (2010). Literacy for children in an information age: Teaching reading, writing, \& thinking (2nd ed.). Belmont, CA: Thomson Wadsworth.

Comber, B., \& Nixon, H. (2011). Critical reading comprehension in an era of accountability. Australian Educational Researcher, 38(2), 167-179. https://doi.org/10.1007/s13384-011-0022-z

Crawford, M. (2015). A study on note taking in EFL listening instruction. In P. Clements, A. Krause, \& H. Brown (Eds.), Proceedings of Japan Association for Language Teaching Conference, 21-24 November 2014. Tokyo: JALT.

Dakhail, N. (2016). A proposed electronic information seeking model to develop secondary stage students' EFL critical reading \& writing skills (Unpublished master's thesis). Mansoura University, Egypt.

Davoudi, M., Moattarian, N., \& Zareian, G. (2015). Impact of Cornell note-taking method instruction on grammar learning of Iranian EFL learners. Journal of Studies in Education, 5(2), 252-265. https://doi.org/10.5296/jse.v5i2.6874

Dean, C., Hubbell, E., Pitler, H., \& Stone, B. (2012). Classroom instruction that works: Research-based strategies for increasing student achievement (2nd ed.). Alexandia, VA: ASCD.

Domenico, P., Elish-Piper, L., Manderino, M., \& L'Allier, S. (2018). Coaching to support disciplinary literacy instruction: Navigating complexity \& challenges for sustained teacher change. Literacy Research \& Instruction, 57(2), 81-99. https://doi.org/10.1080/19388071.2017.1365977

Donohoo, J. (2010). Learning how to learn: Cornell Notes as an example. Journal of Adolescent \& Adult Literacy, 54(3), 224-227. https://doi.org/10.1598/JAAL.54.3.9

El-Sayed, D. (2019). A program based on brain-based learning for develop critical \& creative reading skills among preparatory stage students (Unpublished master's thesis). Ain Shams University, Egypt.

English, J. (2014). Plugged in: Succeeding as an online learner. Boston, MA: Wadsworth.

Esteves, K., \& Whitten, E. (2014). RTI in middle school classrooms: Proven tools \& strategies. Minneapolis, MN: Free Spirit.

Evans, B., \& Shively, C. (2019). Using the Cornell note-taking system can help eighth grade students alleviate the impact of interruptions while reading at home. Journal of Inquiry \& Action in Education, 10(1), 1-35.

Fadhli, M. (2015). The effects of read, encode, annotate, ponder (REAP) strategy, grammar translation strategy $(G T), \&$ reading interest in reading comprehension achievement (Unpublished master's thesis). Sriwijaya University, Indonesia.

Fadhli, M., \& Suhaimi, M. (2017). The effect of read, encode, annotate, ponder (REAP) strategy \& reading interest on reading comprehension achievement. Tarbawi, 13(2), 7-19.

Fisher, D., Frey, N., \& Lapp, D. (2009). Meeting AYP in a high-need school: A formative experiment. Journal of Adolescent \& Adult Literacy, 52(5), 386-396. https://doi.org/10.1598/JAAL.52.5.3

Fitriastuti, W. (2013). The application of the model Read, Encode, Annotate, Ponder (REAP) to improve reading skills of the sixth grade students of SDN 01 Limestone Tulungagung (Unpublished master's thesis). University of Malang, Indonesia.

Forget, M. (2004). Max teaching with reading \& writing: Classroom activities for helping students learn new 
subject matter while acquiring literacy skills. Oxford, UK: Trafford Publishing.

Fujinami, K. (2017). Examining the effects of using picture-based summaries in a flipped classroom model (Unpublished master's thesis). California State University.

Gray, T., \& Madson, L. (2007). Ten easy ways to engage your students. College Teaching, 55(2), 83-87. https://doi.org/10.3200/CTCH.55.2.83-87

Gunning, T. (2012). Building literacy in secondary content areas classrooms. Boston, MA: Pearson.

Hanafy, M. (2018). Raising EFL learners'awareness towards developing critical reading skills: A content-based approach (Unpublished master's thesis). Helwan University, Egypt.

Hathaway, J. (2014). Writing strategies for fiction. Huntington Beach: Shell Education.

Hayati, A., \& Jalilifar, A. (2009). The impact of note-taking strategies on listening comprehension of EFL learners. English Language Teaching, 2(1), 101-111. https://doi.org/10.5539/elt.v2n1p101

Honigsfield, A., \& Dove, M. (2013). Common core for the not-so-common learner: Grades 6-12. Thousand Oaks, CA: Corwin.

Ismail, M. (2015). The effect of using self-regulated learning strategies on developing English critical reading skills of first year experimental secondary school students (Unpublished master's thesis). Suez Canal University, Egypt.

Jacobs, K. (2008). A comparison of two note taking methods in a secondary English classroom. Proceedings of the $4^{\text {th }}$ Annual GRASP Symposium, Wichita State University, 2008 (pp. 119-120).

Jewett, P. (2007). Reading knee-deep. Reading Psychology, 28(2), 149-162. https://doi.org/10.1080/02702710601186365

Johnson, B. (2013). Teaching students to dig deeper: The common core in action. New York: Routledge.

Juniardi, V., Suharjito, B., \& Andayani, M. (2019). Enhancing the eighth-grade students' reading comprehension achievement by using REAP (read, encode, annotate, ponder) strategy. EFL Education Journal, 5(2), 1321-1330.

Kubacak, C. (2017). Student perceptions of the effectiveness of AVID for college readiness (Unpublished doctoral dissertation). Tarleton State University.

Lapp, D., \& Fisher, D. (2009). Essential readings on comprehension. New York: The International Reading Association.

Leu, D., \& Kinzer, C. (2000). The convergence of literacy instruction with networked technologies for information \& communication. Reading Research Quarterly, 35(1), 108-127. https://doi.org/10.1598/RRQ.35.1.8

Lewin, T. (2005, August 17). Many going to college aren't ready, report says. New York Times. Retrieved August 5, 2018, from http://www.nytimes.com/2005/08/17/education/17scores.html

Macdonald, V. (2014). Note taking skills for everyone: Learn the strategies of effective note taking in order to earn maximum grades today! Vancouver, Canada: Martin Knowles.

Magyar, A. (2012). Plagiarism \& attribution: An academic literacies approach. Journal of Learning Development in Higher Education, 4, 1-20.

Manzo, A., \& Manzo, U. (1995). Teaching children to be literate: A reflective approach. New York: Harcourt Brace College.

Marantika, J., \& Fitrawati, F. (2013). The REAP strategy for teaching reading a narrative text to junior high school students. Journal of English Language Teaching, 1(2), 70-77.

Marzano, R., Pickering, D., \& Pollock, J. (2001). Classroom instruction that works: Research-based strategies for increasing student achievement. Alexandria, VA: ASCD.

Mayfield, M. (2014). Thinking for yourself: Developing critical thinking skills through reading \& writing (9th ed.). Boston: Wadsworth Cengage Learning.

McNight, K. (2010). The teacher's big book of graphic organizers: 100 reproducible organizers that help kids with reading, writing, \& the content areas. San Francisco: Jossey-Bass.

McPherson, F. (2018). Effective notetaking (3rd ed.). Willington, New Zealand: Wayz Press. 
Mehmet, T. (2010). The effect of the REAP reading comprehension technique on students' success. Social Behavior \& Personality, 38(4), 553-560. https://doi.org/10.2224/sbp.2010.38.4.553

Miller, M., \& Veatch, N. (2011). Literacy in context: Choosing instructional strategies to teach reading in content areas for students in grades 5-12. Boston, MA: Pearson Education.

Morehead, K., Dunlosky, J., Rawson, K., Blasiman, R., \& Hollis, B. (2019). Note-taking habits of $21^{\text {st }}$ century college students: Implications for student learning, memory, \& achievement. Memory, 27(6), 807-819. https://doi.org/10.1080/09658211.2019.1569694

Mutia, F., Syafar, A., \& Dewi, A. (2016). Applying read, encode, annotate, \& ponder (REAP) technique to develop reading comprehension of the grade X students. English Language Teaching Society Journal, 4(1), $1-11$.

Nielsen, L., \& Webb, W. (2011). Teaching generation text: Using cell phones to enhance learning. San Francisco: Jossey-Bass.

Northey, S. (2005). Handbook of differentiated instruction for middle \& high schools. New York: Routledge.

Nuraeni, T. (2019). The effect of using Cornell-note taking technique to the students of reading comprehension at the eleventh-grade students. Simki-Pedagogia, 3(3), 1-11.

Parrish, B., \& Johnson, K. (2010). Promoting learner transitions to postsecondary education \& work: Developing academic readiness skills from the beginning. Washington, DC: Center for Applied Linguistics.

Pauk, W. (2011). How to study in college (10th ed.). Boston: Wadsworth, Cengage Learning.

Pirozzi, R., Starks-Martin, G., \& Dziewisz, J. (2014). Critical reading, critical thinking: Focusing on contemporary issues (4th ed.). New York: Longman.

Pohtong, K. (2012). Effects of using REAP strategy in Thai instruction on critical reading \& essay writing abilities of ninth grade students. OJED, 7(1), 117-130.

Polleck, J. (2017). Expand your tool kit: Assessing students' reading comprehension \& interpretation. Rutherford County Schools Summer Conference, July 25-26, 2017.

Powell, N., Cleveland, R., Thompson, S., \& Forde, T. (2012). Using multi-instructional teaching \& technology-supported active learning strategies to enhance student engagement. Journal of Technology Integration in the Classroom, 4(2), 41-50.

Quintus, L., Borr, M., Duffield, S., Napoleon, L., \& Welch, A. (2012). The impact of the Cornell note-taking method on students' performance in a high school family \& consumer sciences class. Journal of Family \& Consumer Sciences Education, 30(1), 27-38.

Rashid, S., \& Rigas, D. (2006). E-learning \& note-taking: A comparative study. Proceedings of the $5^{\text {th }}$ WSEAS International Conference on Education \& Educational Technology, Tenerife, Canary Islands, Spain, December 16-18, 2006.

Robinson, C. (2018). Note-taking strategies in the science classroom. Science Scope, 41(6), 22-25. https://doi.org/10.2505/4/ss18_041_06_22

Roe, B., \& Smith, S. (2012). Teaching reading in today's elementary schools (11th ed.). Belmont: Wadsworth.

Rog, L. (2012). Guiding readers: Making the most of the 18-minute guided reading lesson. Ontario, Canada: Pembroke.

Rojas, V. (2007). Strategies for success with English language learners. Alexandria, Virginia: ASCD.

Rubin, A., \& Babbie, E. (2017). Research methods for social work (9th ed.). Belmont, CA: Brooks/Cole, Cengage Learning.

Ruddell, M. (2007). Teaching content reading \& writing (5th ed.). New Jersey: Wiley.

Salkind, N. (2010). Encyclopedia of research design. Thousand Oaks, CA: Sage. https://doi.org/10.4135/9781412961288

Santi, V. (2015). Improving students' reading comprehension by using REAP (read, encode, annotate, ponder) strategy. Journal of Linguistics \& Language Teaching, 2(1), 1-7.

Sejnost, R., \& Thiese, S. (2010). Building content literacy: Strategy for adolescent learner. Maryland: Corwin. https://doi.org/10.4135/9781483350578 
Şen, A., \& Neufeld, S. (2006). In pursuit of alternatives in ELT methodology: WebQuests. The Turkish Online Journal of Educational Technology, 5(1), 49-67.

Smith, A. (2017). SQ3R, Cornell notes, ApSum: The impact of three content literacy strategies on student learning \& the perceptions of these strategies held by fifth-grade teachers \& students (Unpublished doctoral dissertation). Northern Arizona University.

Syafi' 'I, A. (2019). Students' response of using Cornell Note Taking System (CNTS) in listening class. Journal of English Language Teaching \& Islamic Integration, 2(1), 131-145.

Syrja, R. (2011). How to reach \& teach English language learners. San Francisco: Jossey-Bass.

Tasdemir M. (2010). The effects of the REAP reading comprehension technique on students' success. Social Behavior \& Personality, 38(4), 553-560. https://doi.org/10.2224/sbp.2010.38.4.553

Thomson, P., \& Kalmer, B. (2016). Detox your writing: Strategies for doctoral researchers. New York: Routledge.

Tiruneh, D. (2014). The effect of explicit reading strategy instruction on reading comprehension of upper primary grade. International Journal of Education, 6(3), 81-100. https://doi.org/10.5296/ije.v6i3.5989

Tsai-Fu, T., \& Wu, Y. (2010). Effects of note-taking instruction \& note-taking languages on college EFL students' listening comprehension. New Horizons in Education, 58(1), 120-132.

Vacca, R., Vacca, J., \& Mraz, M. (2016). Content area reading: Literacy \& learning across the curriculum (12th ed.). New York: Pearson Education.

Van Blerkom, D. (2012a). College study skills: Becoming a strategic learner (7th ed.). Boston, MA: Wadsworth Cengage Learning.

Van Blerkom, D. (2012b). Orientation to college learning (7th ed.). Boston, MA: Wadsworth.

Werner-Burke, N., \& Vanderpool, D. (2013). No more index cards: No notebooks! Pulling new paradigms through to practice. In K. Pytash, R. Ferdig, \& T. Rasinski (Eds.), Preparing teachers to teach writing using technology (pp. 43-56). Pittsburg, PA: ETC Press.

Zaki, E. (2014). The effect of using electronic mind mapping on developing first year secondary stage students' EFL critical reading skills (Unpublished master's thesis). Ain Shams University, Egypt.

Zasrianita, F. (2016). Using of reading, encoding, annotating, \& pondering (REAP) technique to improve students' reading comprehension. Ta'dib, 19(2), 147-164. https://doi.org/10.31958/jt.v19i2.460

Zhang, Y., Dang, Y., \& Amer, B. (2016). A large-scale blended \& flipped class: Class design \& investigation of factors influencing students' intention to learn. IEEE Transactions on Education, 59(4), 263-273. https://doi.org/10.1109/TE.2016.2535205

Zigo, D., \& Moore, M. (2004). Science fiction: Serious reading, critical reading. The English Journal, 94(2), 85-90. https://doi.org/10.2307/4128779

\section{Copyrights}

Copyright for this article is retained by the author(s), with first publication rights granted to the journal.

This is an open-access article distributed under the terms and conditions of the Creative Commons Attribution license (http://creativecommons.org/licenses/by/4.0/). 